\title{
TRK Inhibitor AZD6918
}

National Cancer Institute

\section{Source}

National Cancer Institute. TRK Inhibitor AZD6918. NCI Thesaurus. Code C80491.

An orally available liquid suspension containing the tropomyosin receptor kinase (Trk) inhibitor AZD6918 with potential antineoplastic activity. AZD6918 binds to Trk, thereby preventing neurotrophin-Trk interaction and Trk activation, and may eventually result in cell cycle arrest and apoptosis of tumor cells that express Trk. Trk, a receptor tyrosine kinase activated by neurotrophins, is mutated in a variety of cancer cell types and plays an important role in tumor cell growth and survival. 